\title{
Rettspsykiatrien etter 22. juli 2011
}

Rettspsykiatrien fikk hard medfart i forbindelse med rettssaken mot Anders Behring Breivik. Noen mente det var for lett å bli funnet utilregnelig og at dette kom av at vi i Norge benytter det såkalte medisinske prinsipp. Noen mente at rettspsykiaterne hadde for mye makt i rettssalene, andre at rettspsykiatrien i Norge ikke er vitenskapelig basert.

De som mener det er for lett å bli funnet utilregnelig, hevder ofte at det psykologiske prinsipp ville gitt færre frifinnelser og at det ville være ønskelig. Det medisinske prinsipp tilsier at man blir frifunnet for en ellers straffbar handling dersom man begikk den mens man var veldig psykisk syk. Det psykologiske prinsipp forutsetter at handlingen ble begått fordi gjerningsmannen var veldig syk. Intuitivt er det det psykologiske prinsipp som er det «riktige», likevel mener jeg at det medisinske prinsipp er å anbefale. Man kan med en viss grad av sikkerhet kartlegge hvor syk en person var på handlingstidspunktet, men det å kartlegge hva motivasjonen var, er svært vanskelig. Det er både et juridisk og et klinisk problem å definere hvor psykisk syk man skal være for å bli funnet utilregnelig. Ingen klinisk diagnose er ekvivalent med lovens utilregnelighetsregel. Symptomtyngden ved psykosesykdommen er utslagsgivende.

Forarbeidene for dagens utilregnelighetsregel skriver seg fra 1980årene og frem til loven trådte i kraft i 2002 (1). Det er nå fremlagt en offentlig utredning med ytterligere presiseringer av utilregnelighetsbegrepet (2), hvor det anbefales at det medisinske prinsipp videreføres. I utredningen diskuteres det hvor syk man må være for å bli frifunnet, men jeg mener utredningen er for mye preget av juridiske resonnementer og for lite av klinisk forståelse av alvorlig psykisk syke. Rettspsykiatrisk forskning burde kunne gi mye mer klinisk informasjon om hvilke symptomer som kjennetegner dem som blir funnet utilregnelige i Norge. Da kunne man ha en debatt om hvorvidt dette er for mange eller for få.

Jeg registrerer at noen mener at de sakkyndige har for mye makt i straffesaker. Dersom det medfører riktighet, er det fordi retten abdiserer. Vi så i Breivik-saken at tingretten ikke abdiserte - den foretok den vurderingen som tilligger retten etter å ha vurdert alle bevisene i saken inklusive de sakkyndiges vurderinger.

Rettspsykiatri forutsetter god diagnostikk, i en del saker også risikovurderinger. Her bygges det på internasjonal vitenskapelig basert kunnskap. Denne delen av rettspsykiatrisk virksomhet er sikkert av varierende kvalitet, som klinisk arbeid ellers.

Det som er spesifikt for rettspsykiatrisk virksomhet, er at kliniske psykiatriske vurderinger anvendes innenfor et rettsområde. De sakkyndige bør være i stand til gjøre en god klinisk utredning, og de bør kunne skrive og fremlegge sin erklæring slik at rettens aktører forstår dem. I straffesaker er det et flertall legdommere, de må forstå den informasjon de får for at dommen skal bli mest mulig riktig.

Etter Breivik-saken er det blitt større interesse rundt forskning som kan gi mer informasjon om de spesifikke rettspsykiatriske utfordringene. Det er dessverre ikke gjort mange analyser av norsk rettspsykiatrisk praksis. Etter min mening er det stort behov for mer kunnskap om gruppen som blir frifunnet på grunn av psykose og om gruppen som blir dømt selv om de har alvorlige diagnoser. Vi har behov for å vite hvorledes de sakkyndige har vurdert observandene og hvilke momenter domstolene har lagt spesiell vekt på.
Skeie \& Rasmussen gir i dette nummer av Tidsskriftet et bidrag til slik kunnskap (3). Artikkelen er en psykologisk analyse av dommer i saker der den siktede er blitt funnet utilregnelig etter det medisinske prinsipp på grunn av psykose. Forfatterne har vurdert hvorvidt det fremgår av dommen om det er en sammenheng mellom sykdom og de pådømte forhold. De har funnet at dette er regelen ved alvorlige voldshandlinger som drap, men i mindre grad til stede ved vinningsforbrytelser og i narkotikasaker. Deres funn kan derfor underbygge en oppfatning av at det ved bruk av det psykologiske prinsipp i strafferetten ville blitt flere domfellelser.

Forfatterne har vurdert et spørsmål som ikke er tema i norsk rett sammenhengen mellom sykdom og straffbar handling. De presenterer data om dette, men det er vanskelig å vite hvor presist de har kunnet besvare sitt spørsmål. Dersom de også hadde vurdert de rettspsykiatriske erklæringene, ville dette gitt mer informasjon, og dersom de sakkyndige i sin tid hadde hatt som mandat å belyse sammenheng, ville problemstillingen vært enda bedre belyst. Men hva som egentlig foregikk i hodet på gjerningsmannen, vil vi aldri kunne vite eksakt.

Den økte interessen for rettspsykiatri vi har sett etter Breivik-saken bør opprettholdes. Det er satt i gang flere interessante forskningsprosjekter (4). Et stort hinder i den sammenheng er at de etiske forskningskomiteer mener rettspsykiatriske erklæringer faller inn under helseforskningsloven når de studeres av helsepersonell og derfor krever samtykke fra domfelte. Erfaring tilsier at rettspsykiatrisk observerte ikke samtykker til at avgitte erklæringer blir brukt i forskning. Dette fører til at det blir vanskelig å få tilgang til et representativt utvalg rettspsykiatriske erklæringer til psykiatrisk forskning.

Vi har en lovgivning som hjemler frifinnelse på grunn av utilregnelighet, særreaksjonsdommer og forvaringsdommer for dem som blir betraktet som særlig farlige. Disse dommene bygger delvis på informasjon fra rettspsykiatriske vurderinger. Da er det ille at vi vet så lite om populasjonen og premissene i dommene.

\section{Randi Rosenqvist}

randi@rosenqvist.no

Randi Rosenqvist (f. 1951) er spesialist i psykiatri og ansatt ved Ila fengsel og forvaringsanstalt. Hun var tidligere overlege ved Regional sikkerhetsavdeling, Gaustad, og har vært leder for Den rettsmedisinske kommisjon. Forfatter har fylt ut ICMJE-skjemaet og oppgir ingen interessekonflikter.

Litteratur

1. NOU 1990: 5, Ot.prp nr. 87(1993-94), Ot.prp nr. 46 (2000-2001), Innst.0. nr. 34 (1996-97), Innst.0.nr. 113 (2000-2001).

2. Norges offentlige utredninger. Skyldevne, sakkyndighet og samfunnsvern. NOU 2014: 10.

3. Skeie CA, Rasmussen K. Vurdering av årsakssammenheng mellom sykdom og kriminell handling hos utilregnelige. Tidsskr Nor Legeforen 2015: 135. 327-30

4. SIFER - nasjonalt kompetansesenternettverk i sikkerhets-, fengsels- og rettspsykiatri. http://sifer.no/om_sifer (4.2.2015)

\section{Podkast på www.tidsskriftet.no}

